\title{
The Implementation of Value Clarification Technique (VCT) Learning Model to Improve Social Care Character in Social Science Learning
} (Classroom Action Research Class VIII-L SMP Negeri 29 Bandung)

\author{
Ninis Khairunisa \\ e-mail: niskhalpu@gmail.com
}

\begin{abstract}
This study started from the problems that the author finds in class VIII-L SMP Negeri 29 Bandung where most students have not shown the character of social care. They are less concerned about others seen from behavior, such as: lack of respect to others, and less attention to the teachers and other students. Students seem individualistic and annoy or taunt their classmates with harsh words. From these findings, the author chose to do classroom action research (PTK) with Kemmis and Taggart model. Data analysis technique is qualitative and quantitative. In this study, the author makes observation as much as three cycles. In this study, value clarification technique (VCT) learning model is chosen to guide students to understand, clarify, and implement social care values in daily life including at class. In attempt to
\end{abstract}

\section{INTRODUCTION}

Getting from the results of initial observations made in class VIII-L SMP Negeri 29 Bandung, the author found several problems related to the lack of social character of students. Some of the problems that the author finds are: first, students tend not to care about learning and cannot appreciate others by showing less attention to the explanation of teacher and other students. Second, they bully each other. Third, some students look often annoying other students. Fourth, they seem lack of cooperation each other. Fifth, students are individualistic in group work and tend to interact with students who are close to them alone. Sixth, teacher is less assertive in warning students who show less good attitude.

The findings above show that although character education has been taught in formal schools, the social care character that is one of the characters expected by the students appears less reflected in the behavior of students in the classroom. IPS education is closely related to character education and value education, in accordance with the IPS education objectives themselves, so that students become good citizens. Social science is needed to prepare the next generation of nation with character and national spirit.

This problem needs to be immediately dissolved because the teenager who literally is the student is the hope of the nation in the future. Therefore, as a change agent students need to be equipped with improve the students social care character, the author selects five indicators adjusted to the problems found at class. Based on the study that has been conducted, the result is obtained that: first, the planning that has been prepared by the author works well; second, the implementation of the VCT learning model is conducted three cycles with one action in the cycles 1 and 2 and two actions in cycle 3; third, it reflects the obstacles experienced by each cycle; fourth, the results obtained after implementing the VCT model to cycle 3 show that the students social care character has increased.

Keywords: social care character in Social Science learning, value clarification technique (VCT) learning model

social care value. Each student has potential to be in a good or bad side. Therefore, education is used as a means to develop the character of students from an early age. Building character in students requires a long process and not easy. Education at school needs not only to develop cognitive abilities, but also needs to be emphasized social skills to be able to build the character of students.

The increase of care character through IPS learning cannot be separated from the value of education that is integrated in IPS learning. IPS teaches the existing value system in society including human values such as social care. Value learning in IPS should be able to develop social awareness and cultivate good values in students. The cultivation of basic and fundamental values in students will develop positive student attitudes and characters.

To improve students' social care character, the author applies the Value Clarification Technique (VCT) learning model. Value Clarification Technique (VCT) by Taniredja (2011, pp. 88) is a learning technique to assist students in achieving and determining a value that is considered good in dealing with a problem through the process of analyzing the value that already exists and is embedded in student self. Clarifying techniques can be used in IPS learning to encourage students to analyze issues that contain the values of social care character. According to Djahiri (in Taniredja et al, 2011, pp. 91), VCT has the advantage of effective learning, which is able to nurture and instill values and morals in the internal aspects of the students, able to clarify and disclose the contents of material messages delivered, 
which will further facilitate teacher to convey meaning or message of value, able to clarify and assess the quality of students 'self-moral values, see the value that exists in others, and understand the moral values that exist in real life, able to invite, involve, nurture, and develop students' self potential, especially developing potential attitude, able to provide a number of learning experiences from various life, able to ward off, negate, intervene, and integrate various moral values and value systems and morals that exist in a person, giving a picture of moral values that should be accepted and guided and motivated to live worthy and high morals.

From several advantages of Value Clarification Technique learning model (VCT) according to Djahiri above can be seen that VCT learning model provides an opportunity for students to describe the values contained in life. The value of life can be social caring. Through the value clarification technique learning model (VCT), in addition to conveying the material to be conveyed, the teacher can also assess the extent to which the moral values of the students so that the social character of students can be seen. Based on the background of the problem, the author determines the problem formulation that is; First, how is the planning of applying the value clarification technique learning model (VCT) to improve the social caring character of the students in IPS learning in Class VIII-L SMPN 29 Bandung?; Second, how is the implementation of the application of value clarification technique learning model (VCT) to improve students' social caring character in IPS learning in Class VIII-L SMPN 29 Bandung?; Third, what are the obstacles faced by teacher in applying the value clarification technique learning model (VCT) in Class VIII-L SMPN 29 Bandung ?; Fourth, how does the social caring character of the students in the class after applying the value clarification technique learning model (VCT) in IPS learning in Class VIII-L SMPN 29 Bandung?

\section{STUDY METHOD}

The method used in this study is Classroom Action Research (PTK) with Kemmis and Taggart research design. According to Wiraatmadja (2005, p.66) the design of this study is a spiral system consisting of four stages: planning, action, observe, and reflection. In this study, the author conducted three cycles with one action in cycle 1 and 2, as well as two actions in cycle 3 . In collecting the required data in the field, it takes some research tools. The tools used by the author in collecting data are field note, interview guide, observation sheets, and documentation. Data collection techniques are conducted through observation, interviews, and documentation studies. From the data collection, data analysis techniques conducted by the author ie data reduction, data display, as well as verification and conclusion. The technique of data analysis in this study use descriptive quantitative data technique. There are 6 observed aspects from five indicator of social caring character which counted to look for average score achievement of social caring character of student. Here is a formula used by the author to find the average percentage of social caring of students:

Percentage Value $=($ Number of Scores $) /($ Maximum Score) $x 100=n$

\begin{tabular}{|l|l|}
\hline Average Score & Categorie \\
\hline $66,8 \%-100 \%$ & Good \\
\hline $33,4 \%-66,7 \%$ & Enough \\
\hline $0 \%-33,3 \%$ & Less \\
\hline
\end{tabular}

\section{RESULTS AND DISCUSSION}

Study planning refers to the results of preobservational conducted by the author in class VIII-L SMP Negeri 29 Bandung. The author formulates the planning that refers to the preparatory phase that Zakiyah and Rusdinan (2014, pp. 194) describe the process of VCT learning activities, namely, first, preparing the RPP according to the subject. RPP is part of the planning that is very important because it is a reference of author in applying the model of learning. Referring to Komalasari's statement (2010, pp. 194) which states that RPP is a learning signpost of the final goal to be achieved, what teaching materials will be delivered, what learning method will be used, what learning steps will be undertaken, what tools and media will be used, and what form of assessment will be implemented. Therefore, the author compiles RPP that is tailored to the material to be studied.

Second, set the part of the disciplinary material to be presented through value analysis. Sanjaya (2011, p.283) argues that the VCT may facilitate the search and determine a value that is considered good in facing an area of dialogue through the process of analyzing the value that has been planted in the study. Therefore, planning the discipline material is necessary to link the material with the targeted values.

Third, develop a learning scenario. The learning scenario of the author stacked before applying the VCT learning model through RPP. The learning 
scenario that author arrange each cycle is tailored to the obstacles that the author is experiencing with the goal of overcoming these obstacles.

Fourth, prepare stimulus media for VCT. The media that author use varies like picture and video learning. Preparing instructional media aims to make it easier for students to analyze examples of problems that teacher has. This is in accordance with the opinion of Djahiri (1985, p.63) which explains preparation made by the teacher is to review again clarity of target value desired. In addition, finding and determining the stimulus media in the form of images, photos for VCT techniques (reportage/coverage), images or other valuable items for VCT (accurate and thorough analysis), stories or news clippings/articles/magazines/books for stimulus media (Story analysis), Stories that are not cut or resolved for VCT (incompatible story), Prepare a work sheet that contains detailed guidance for students in VCT. The worksheet in this study is a matter of analysis and matter of VCT table list of values as well as good and bad tables. At the step of applying VCT learning students are free to determine the value and consider the value they choose. After choosing a grade, the students will consider the value to be a part of themselves and apply it in daily life. In addition to the above learning steps, VCT learning has several processes that must be followed by the steps of applying appropriate learning. At the implementation stage in cycle 1 the author tells the students that they will apply the value clarification technique learning model (VCT), then the author gives the stimulus in the form of the picture with the problem which must be analyzed by the students. In cycles 2 and 3 the author use video media that will students analyze or dig the values of the stimulus that has been given. The use of image or video media is intended to make students understand better the material and the value being studied. According to Rahayudi (2013, pp. 4) the application of the VCT learning model begins with a media/stimulus outburst on the cross-sectional side of a confusing moral value and can stabilize the balance of cognitive processes of the student. Then the students are involved to investigate the problem with the discussion and choose how to solve the problem with the group (choosing). After that the teacher sets the students they can feel or choose the value chosen by compiling the discussion results. From the stimulator, the author sees to the action and the spontaneous reactions of the students, then afterwards guides the students to explain the values they have analyzed and carry out the guided dialogue through the teacher's questions. The teacher argues the arguments proposed by the students related to the values of social care. It is in line with the opinion of Anggrani (2013, p. 4) which states that in learning value clarification technique (VCT), the teacher guides the students in effect in developing their understanding and recognition of personal values, making decisions, and acting according to the decisions taken, with questions to develop students' skills in the process of assessing, improving and reinforcing the values that students have. Through this activity the teacher can see students' ability to understand or dig a value from a problem. Then in the last stage the teacher guides the students to conclude the learning.

The VCT learning model must be able to train students to have awareness or understanding of a value. According to Taniredja (2011, pp. 88) one of the aims of VCT is to instill students' values through the means of the logical and the students, so that the ending of these issues will be the property of the students as a moral awareness process rather than a moral obligation. Based on these statements, author applies VCT with stimuli in the form of social problems that occur around students. In cycles 1 and 2 the problem that is discussed is poverty, students are trained to have sensitivity to the problem by determining or clarifying social caring values through the issue. Students are asked to provide solutions or actions they will take if they find the problem. In cycle 3 the problem of stimulus is about tax corruption. Students are asked to analyze the character that must be followed by a tax clerk who has social concern. Through social issues, the development of social caring character through VCT learning model of students inculcated the value of social care by reviewing concrete and logical problems so that it can be accepted by students so that students will be encouraged to solve problems that occur in the surrounding environment.

After the application of Value Clarification Technique (VCT) learning model in cycle 1, the author discussed with partner teacher to reflect on teaching and learning activities that have been done. Based on the results of the reflection, the author found some obstacles. Obstacles when execution of action. First, the use of images as a medium of learning makes the students a little difficulty in analyzing the values contained in the picture. In addition students are less motivated in analyzing images. Students often ask the teacher about the image that must be analyzed and how to do it. According to Djahiri in Taniredja et al (2011, pp. 91) one of the benefits of VCT is able to clarify and reveal the contents of material messages delivered, which will further facilitate the teacher to convey the meaning or message of value. However, in the application of VCT in cycle 1, the author found that students had difficulties in analyzing images that can produce many diverse perceptions. Because of these obstacles, students become less aware of the values of 
social care targeted by the author and must re-convey messages or values to be conveyed in the picture.

Second, the class situation is less conducive, especially when there are other students who speak in front of the class. In addition, there are some students who mock each other and disturb their friend during the learning process. Zubaedi (2011, pp. 79) adds that caring is the ability to demonstrate understanding of others and treat them well, with compassion being generous, and in the spirit of forgiveness. Attitudes that students show when learning takes place that has not been able to apply the values of social care with mocking or disturbing his friends showed low awareness of students against others. Some of the students who exhibit such a bad attitude do not change their character only with advice and reprimands. Students often repeat their bad habits despite being reprimanded by the teacher.

Third, students are less able to work together, so that group activities are dominated by only a few people. Darmiyati Zubaedi (2012, p. 76) explains that social caring is an act of always willingness to help the people in need. Therefore, students who are less able to cooperate or help each other while doing group work reflect the low level of social caring character of the students.

In cycle 2, the author also found some obstacles when applying the VCT learning model. The obstacles are:

First, time is not enough so that the presentation is done by representatives from 1 group only. Optimized time on watching videos and the author would like to invite students to argue so that time is insufficient if representatives of all groups are advancing for presentations. Second, students are less able to work well together. Some students are less able to maintain class harmony by cooperating while doing group work. Third, some students are indifferent and do not listen while their friends are explaining the results of the analysis in front of the class. Fourth, the students appear to be saturated by only doing group activities and value clarification is the result of group analysis so that it does not train students to clarify and understand the value individually. While in cycle 3 , the obstacles experienced by the author are almost solved completely. However, the obstacles that author encounter are only a few students who are active who often express opinions or arguments.

Based on the data obtained from observation, class VIII-L experienced improvement of social care character after the implementation from cycle 1 up to cycle 3 . In this study there are five indicators as a measure to find out the level of social character of the students. The author develops social care indicators based on the social indicators according to Samani and Hariyanto (2012, pp. 51) adapted to the analysis of problems in the classroom, listening to others, tolerating differences, working together, treating others well, not degrading others. From some of these indicators, the author develops it into 6 observed aspects ie listening to teacher and other students' explanation, accepting friend's opinion, helping each other while doing group work, not disturbing other students, and not mocking friends while learning takes place. Some of these aspects are observed and assessed by percentage averages to see the extent to which the student's social caring character is elevated. Here is an improved graph of social caring character.

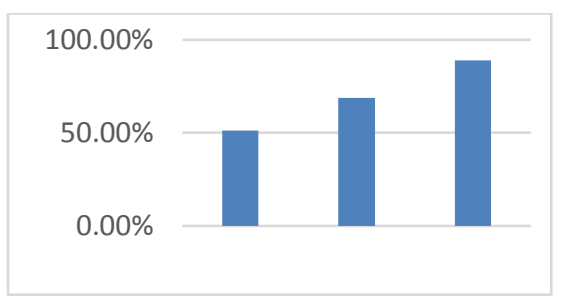

Based on the graph, it can be seen that in the first cycle the result of observation of social caring character of the students get the percentage of $51,2 \%$. At the beginning of applying Value Clarification Technique learning model (VCT) that is in cycle 1, the student had difficulties in analyzing the picture and exploring the social care values that the author targets. According to Sapriya (2011, pp. 53) in essence value is something of value, value is a set of beliefs or principles of behavior that have personified within a particular person or group of people when thinking or acting. Therefore, to instill a value that is a principle that tends to be a person's character, it is difficult if taught at a single planting value only.

In cycle 2, the percentage gained from the observation result of the students was $68.8 \%$. This result shows an increase in the social caring character of the students compared to cycle 1 . The obstacles found in cycle 1 , are quite capable of resolving although there are some obstacles that author experienced in the second cycle action. Students are mostly less conducive when following learning, with the use of discipline cards enough to make students more conducive to learning. With the help of video media, students are better able to understand social caring values. With an understanding of the value of social care, students can imitate the values contained in the video and then implement it in everyday life including when teaching and learning activities. 
In cycle 3, the results of the observation assessment showed a significant increase of $89 \%$. Some of the obstacles that author experienced in cycle 2 have begun to be resolved in cycle 3 . Almost all students are able to cooperate and only 1 student is less able to cooperate. Students are able to appreciate friends in listening to other students who are talking in front of the class. Students have been able to understand and present the values and characters that must be imitated from the characters in the video. Zubaedi (2011, pp. 79) states caring is the ability to demonstrate understanding of others and treat them well, with charity being generous, and in the spirit of forgiveness. Based on that opinion, in cycle 3 the students already have a concern with treat other students well. Almost all students are able to listen to friends and not mock or disturb other students while learning takes place. In addition, in cycle 2 students have been able to work together by helping each other in doing group work.

Based on the development of social care characters obtained from the results of students' observation assessment, it shows that the social caring character of the students increases gradually in each cycle. Djahiri in Al-lamri and Ichas (2006, pp. 87) points out that the VCT represents a vehicle for showing and expressing the values of students. Therefore, VCT can help students to define and express social caring values and then implement those values in everyday life. The habit of implementing social caring values will develop students' social caring character. Through the application of VCT model Students who initially still show bad habits such as interrupt and mock friends during classroom learning, after the implementation of learning model VCT students are able to change these bad habits. In addition, students have demonstrated customs that match the social care aspects.

Lickona (2012, p.75) which states that caring attitude (with the meaning of "sacrifice for) helps us to not only know what our responsibilities are, but also feel it. In accordance with this theory, through the VCT learning model, students have been able to execute their responsibilities by working on both group and individual questions and being able to show tolerant attitude to differences by accepting other people's opinions and listening to their friends' mates.

According to Taniredja (2011, pp. 88) one of the aims of VCT is to instill students' values through the means of the logical and the students, so that the ending of these issues will be the property of the students as a moral awareness process rather than a moral obligation. In this case, the application of the VCT learning model that teachers apply to help students determine or analyze the values of social care through a logical way of presenting the social problems that exist in the environment around the students so that encourage students to implement these values in everyday life including when learning in the classroom.

The Value Clarification Technique (VCT) learning model helps teachers to instill social care values targeted by researchers in accordance with the problems encountered in the classroom, especially when researchers use video media. Through the help of video media, students can explore and emulate the values of social care. Based on interviews between author and students, video media can motivate students to do good things exemplified in the video. In addition, the video media helps make it easier for students to understand the value of social care and the material being studied.

\section{CONCLUSION}

Based on Classroom Action Research that has been done, it can be concluded that:

First, the planning of VCT learning model implementation is done by preparing instruction plan (RPP) along with learning scenarios and materials that will be studied by the students. In addition, the author prepares a learning media that is used as a stimulus for students in analyzing a value.

Second, the implementation of VCT learning model in accordance with the planning has been made. Students are asked to analyze the images in cycle 1, whereas in cycles 2 and 3 the students analyze the videos in groups. After that, students are asked to explain the results of their analysis in front of the class.

Third, when applying the value clarification technique learning model (VCT), the author encounters several obstacles. The most prominent obstacle is the lack of student cooperation while doing group work. Cooperation is one of the aspects that become obstacles in cycles 1 and 2, until the third cycle it can be solved through improved planning and specific actions so that the target of social character building improvement can be achieved.

Fourth, the results of observation of social caring characteristic indicate improvement of social care character in every cycle. Through VCT learning model, students become more understanding about social matter and social values and make learning IPS 
more meaningful. In addition, through the model of VCT learning, students inculcated social caring values through a logical way of presenting the problems that occur in the environment around the students, so that they will foster student sensitivity. This sensitivity is a process for developing social caring character by solving social problems in the environment. Based on these results, the author concluded that the application of VCT learning model is able to improve the character of students care.

\section{THANK-YOU NOTE}

The author wish to thank the lecturers of Drs. H. Eded Tarmedi, MA and Mr. Drs. H. Faqih Samlawi, MA as a lecturer II in providing guidance, and motivation so that this journal can be published in the journal IPS.

\section{BIBLIOGRAPHY}

Al-lamri, dkk. (2006.) Pengembangan Pendidikan Nilai dalam Pembelajaran Pengetahuan Sosial di Sekolah Dasar. Jakarta: Dirjendikti.

Darmiyati, Zuchdi. (2011). Pendidikan Karakter dalam Prespektif Teori dan Praktek. Yogyakarta: UNY Press.

Djahiri, A. Kosasih. (1985). Strategi Pengajaran Afektif Nilai Moral VCT dan Games dalam VCT. Bandung: Jurusan Pendidikan Moral dan Kewarganegaraan FPIPS IKIP.

Dw. KD Tastra, Dkk. (2013). Pengaruh Model Pembelajaran VCT Berbantuan Media Microsoft PowerPoint terhadap Prestasi Belajar PKn Siswa Kelas $V$ SD Gugus II Kecamatan Tegallalang. [Online] tersedia di: http://ejournal.undiksha.ac.id/index.php/JJPGSD /article/download/736/609. Vol 1 [21 Februari $\underline{20171}$

Komalasari, Kokom. (2013). Pembelajaran Kontekstual: Konsep dan Aplikasi. Bandung: PT Refika Aditama.

Lickona, Thomas. (2012). Educating for Character: Mendidik untuk Membentuk Karakter. Jakarta: Bumi Aksara.

Samani, Muchlas dan Hariyanto. (2012). Konsep dan Model Pendidikan Karakter. Bandung: PT Remaja Rosdakarya.
Sanjaya, Wina. (2011). Strategi Pembelajaran Berorientasi Standar Proses Pendidikan. Jakarta: Prenada Media Group.

Sapriya. (2012). Pendidikan IPS: konsep dan pembelajaran. Bandung: PT Remaja Rosdakarya.

Taniredja, dkk. (2011). Model-model Pembelajaran Inovatif. Bandung: Alfabeta.

Wiriaatmaja, Rochiati. (2005). Metode Penelitian Tindakan Kelas. Bandung: Program Pascasarjana UPI dan PT Remaja Rosdakarya.

Wyn Sudiana, dkk. (2013). Pengaruh Model Pembelajaran Value Clarification Technique Berbantuan Media Gambar terhadap Nilai Karakter Siswa Kelas V SD Gugus VI Tajun. [Online] tersedia di: http://ejournal.undiksha.ac.id/index.php/JJPGS D/article/download/865/737. Vol 1 [20 Februari 2017]

Zakiyah dan Rusdinana. (2014). Pendidikan Nilai (Kajian Teori Dan Praktik Di Sekolah). Bandung: Pustaka Setia

Zubaedi. (2012). Desain Pendidikan Karakter: Konsepsi dan Aplikasinya dalam Lembaga Pendidikan. Jakarta: Kencana Prenada Media Grou 